\title{
Cytokine release syndrome: grading, modeling, and new therapy
}

Delong Liu $^{1 *}$ (D) and Juanjuan Zhao ${ }^{2}$

\begin{abstract}
Genetically modified T cells that express a chimeric antigen receptor (CAR) are opening a new frontier in cancer immunotherapy. CAR T cells currently are in clinical trials for many cancer types. Cytokine release syndrome (CRS) and neurotoxicities (CAR-related encephalopathy syndrome, CRES) are major adverse events limiting wide deployment of the CAR T cell treatment. Major efforts are ongoing to characterize the pathogenesis and etiology of CRS and CRES. Mouse models have been established to facilitate the study of pathogenesis of the major toxicities of CAR T cells. Myeloid cells including macrophages and monocytes, not the CAR T cells, were found to be the major cells mediating CRS and CRES by releasing IL-1 and IL-6 among other cytokines. Blocking IL-1 or depletion of monocytes abolished both CRS and CRES, whereas IL- 6 blocker can ameliorate CRS but not CRES. Therefore, both IL-1 and IL-6 are major cytokines for CRS, though IL-1 is responsible for CRES. It was also demonstrated in the mouse models that blocking CRS does not interfere with the CAR T cell antitumor functions. We summarized new developments in the grading, modeling, and possible new therapeutic approaches for CRS and CRES in this review.
\end{abstract}

\section{Background}

Genetically modified T cells that express a chimeric antigen receptor (CAR) are opening a new frontier in cancer immunotherapy [1-6]. Clinical trials of CAR $T$ cells have been reported for many cancer types throughout the world [7-20]. Two types of CD19-directed CAR T cells, tisagenlecleucel and axicabtagene ciloleucel, have been approved for treatment of refractory/relapsed (R/R) non-Hodgkin lymphoma, whereas tisagenlecleucel was also approved for treatment of R/R acute lymphoid leukemia [15, 21-23].

Currently, the structure of a CAR contains an antigen-recognition domain, a transmembrane domain, a costimulatory segment, and a signaling domain [1, 24-26]. A single-chain fragment of variable region $(\mathrm{scFv})$ replaces the conventional $\mathrm{T}$ cell antigen recognition domain. Therefore, the $\mathrm{scFv}$ confers the specificity of the engineered CAR T cells. More sophisticated CARs are being engineered, leading to more flexibility and controllability [27-29].

CAR $\mathrm{T}$ cells currently are in clinical trials for both hematological malignancies and solid tumors [11, 30-39]. Cytokine release syndrome (CRS) and neurotoxicities (CAR-related encephalopathy syndrome, CRES) are major

\footnotetext{
* Correspondence: DELONG_LIU@NYMC.EDU

'Department of Oncology, The First Affiliated Hospital of Zhengzhou

University, Zhengzhou 450052, China

Full list of author information is available at the end of the article
}

adverse events limiting wide deployment of the CAR T cell treatment. Major efforts are ongoing to characterize the pathogenesis and etiology of CRS and CRES [40]. Mouse models of CRS have been established to facilitate the study of pathogenesis of the major toxicities of CAR T cells in animals. We summarized new developments in the grading, modeling, and therapeutic approaches for CRS and neurotoxicities in this review.

\section{CRS grading}

CRS has characteristic clinical presentations, manifested typically with high fever, hypotension, hypoxia, and respiratory distress [41-44]. Organ dysfunctions such as liver transaminitis and renal insufficiency can occur. CRS toxicities occur as frequently as $90 \%$, half of which is severe. Severe CRS complications are life-threatening and frequently require ICU care with vasopressors and/or ventilation support. The severities of CRS and neurotoxicities are directly related to the disease burden of ALL and the magnitude of CAR T cell expansion [22, 45, 46].

Several CRS grading systems have been proposed (Table 1) [41-44]. The CTCAE grading of CRS was initially developed for CRS related to blinatumomab infusion. The Lee and Neelapu grading systems allowed low-dose vasopressors and low requirement for oxygen $(<40 \%)$ as grade 2 , whereas the Penn grading scale 
Table 1 CRS grading scales: Penn grading scale, CTCAE v4.0, 2014 Lee et al. scale, and MDACC grading

\begin{tabular}{|c|c|c|c|c|}
\hline & Penn grading scale & CTCAE v4.0 & 2014 Lee et al. & MDACC \\
\hline Grade 1 & $\begin{array}{l}\text { Mild reaction: treated with } \\
\text { supportive care such as } \\
\text { antipyretics and antiemetics }\end{array}$ & $\begin{array}{l}\text { Mild reaction; infusion } \\
\text { interruption not indicated; } \\
\text { intervention not indicated }\end{array}$ & $\begin{array}{l}\text { Symptoms are not life- } \\
\text { threatening and require } \\
\text { symptomatic treatment only, } \\
\text { e.g., fever, nausea, fatigue, } \\
\text { headache, myalgias, and malaise }\end{array}$ & $\begin{array}{l}\text { Temperature } \geq 38^{\circ} \mathrm{C} \text { (fever) or } \\
\text { grade } 1 \text { organ toxicity }\end{array}$ \\
\hline Grade 2 & $\begin{array}{l}\text { Moderate reaction: some signs } \\
\text { of organ dysfunction (e.g., grade } 2 \\
\text { creatinine or grade } 3 \text { LFTs) related } \\
\text { to CRS and not attributable to any } \\
\text { other condition. Hospitalization for } \\
\text { management of CRS-related } \\
\text { symptoms, including fevers with } \\
\text { associated neutropenia and need } \\
\text { for IV therapies (not including fluid } \\
\text { resuscitation for hypotension) }\end{array}$ & $\begin{array}{l}\text { Therapy or infusion interruption } \\
\text { indicated but responds promptly } \\
\text { to symptomatic treatment (e.g., } \\
\text { antihistamines, NSAIDs, narcotics, } \\
\text { IV fluids); prophylactic } \\
\text { medications indicated for } \leq 24 \mathrm{~h}\end{array}$ & $\begin{array}{l}\text { Symptoms require and respond } \\
\text { to moderate intervention. } \\
\text { Oxygen requirement }<40 \% \text { or } \\
\text { hypotension responsive to fluids } \\
\text { or low-dose pressors or grade } 2 \\
\text { organ toxicity }\end{array}$ & $\begin{array}{l}\text { Systolic blood pressure } \\
<90 \mathrm{mmHg} \text { (hypotension) but } \\
\text { responds to IV fluids or low-dose } \\
\text { vasopressors or needing oxygen } \\
\text { (FiO2 < 40\%) for } \mathrm{SaO} 2>90 \% \\
\text { (hypoxia) or grade } 2 \text { organ } \\
\text { toxicity }\end{array}$ \\
\hline Grade 3 & $\begin{array}{l}\text { More severe reaction: } \\
\text { hospitalization required for } \\
\text { management of symptoms related } \\
\text { to organ dysfunction, including } \\
\text { grade } 4 \text { LFTs or grade } 3 \text { creatinine } \\
\text { related to CRS and not } \\
\text { attributable to any other } \\
\text { conditions; this excludes } \\
\text { management of fever or myalgias; } \\
\text { includes hypotension treated with } \\
\text { IV fluids (defined as multiple fluid } \\
\text { boluses for blood pressure } \\
\text { support) or low-dose vasopressors, } \\
\text { coagulopathy requiring fresh } \\
\text { frozen plasma or cryoprecipitate } \\
\text { or fibrinogen concentrate, and } \\
\text { hypoxia requiring supplemental } \\
\text { oxygen (nasal cannula oxygen, } \\
\text { high-flow oxygen, CPAP, or BiPAP). } \\
\text { Patients admitted for manage } \\
\text { ment of suspected infection due } \\
\text { to fevers and/or neutropenia may } \\
\text { have grade } 2 \text { CRS }\end{array}$ & $\begin{array}{l}\text { Prolonged reaction (e.g., not } \\
\text { rapidly responsive to } \\
\text { symptomatic medication and/or } \\
\text { brief interruption of infusion); } \\
\text { recurrence of symptoms } \\
\text { following initial improvement; } \\
\text { indicated for clinical sequelae } \\
\text { (e.g., renal impairment, } \\
\text { pulmonary infiltrates) }\end{array}$ & $\begin{array}{l}\text { Symptoms require and respond } \\
\text { to aggressive intervention. } \\
\text { Oxygen requirement } \geq 40 \% \text { or } \\
\text { hypotension requiring high-dose } \\
\text { or multiple pressors or grade } 3 \\
\text { organ toxicity or grade } 4 \\
\text { transaminitis }\end{array}$ & $\begin{array}{l}\text { Systolic blood pressure } \\
<90 \mathrm{mmHg} \text { (hypotension) and } \\
\text { needs high-dose or multiple } \\
\text { vasopressors or needing oxygen } \\
\text { (FiO2 } \geq 40 \% \text { ) for } \mathrm{SaO} 2>90 \% \\
\text { (hypoxia) or grade } 3 \text { organ } \\
\text { toxicity or grade } 4 \text { transaminitis }\end{array}$ \\
\hline Grade 4 & $\begin{array}{l}\text { Life-threatening complications } \\
\text { such as hypotension requiring } \\
\text { high-dose vasopressors and }{ }^{\mathrm{a}} \\
\text { hypoxia requiring mechanical } \\
\text { ventilation }\end{array}$ & $\begin{array}{l}\text { Life-threatening consequences; } \\
\text { pressor or ventilator support } \\
\text { indicated }\end{array}$ & $\begin{array}{l}\text { Life-threatening symptoms. } \\
\text { Requirements for ventilator } \\
\text { support or grade } 4 \text { oxygen } \\
\text { toxicity (excluding transaminitis) }\end{array}$ & $\begin{array}{l}\text { Life-threatening hypotension or } \\
\text { needing ventilator support or } \\
\text { grade } 4 \text { oxygen toxicity } \\
\text { (excluding transaminitis) }\end{array}$ \\
\hline
\end{tabular}

BiPAP bilevel positive airway pressure, CPAP continuous positive airway pressure therapy, CRS cytokine release syndrome, CTCAE Common Terminology Criteria for Adverse Events, IV intravenous, LFT liver function test, NSAID nonsteroidal anti-inflammatory drug, $\mathrm{FiO}_{2}$ fraction of inspired oxygen, $\mathrm{SaO}_{2}$ arterial oxygen saturation ${ }^{\mathrm{a}} \mathrm{See}$ specific definition of high-dose vasopressors [41]

placed those to grade 3 when IV fluid resuscitation, any vasopressors, and/or oxygen is required. Clinically, it is more practical to place those who require any vasopressors to grade 3 (severe) since ICU care is required in most hospitals in such situation, whereas those who only require low-flow oxygen (mild hypoxia) and fluid resuscitation (mild hypotension) belong to grade 2 . The different CRS grading system may have accounted for the reported differences in the rate of severe grades 3-4 CRS in different clinical trials [22, 47].

Cytokine storm appears to be a distinct entity [41], even though clinical manifestations are similar to those of CRS. Cytokine storm appears to be mainly a result of non-specific $\mathrm{T}$ cell activation and occurs typically early in the course, shortly after CAR $\mathrm{T}$ cell infusion. The major cytokines in cytokine storm are TNF and IFN gamma [41]. Steroids are usually the first choice of therapy. CRS is usually the direct consequence of CAR T cell activation upon engagement of CAR with specific antigens. Therefore, CRS onset can vary in different diseases as well as with different CARs. For CTL019 clinical trials, the CRS onset timing ranged from 1 to 71 days [41], though most cases occurred between 1 and 14 days. The CRS onset timing in these CTL019 (tisagenlecleucel) trials varies according to the severities, with grades 1-3 CRS onset between a median of 8 and 9 days, whereas grade 4 CRS onset occurred at a median of 1 day (range 1-8 days) [8, 41, 48]. The median duration of CRS was reported to be between 5 and 12 days (range 1-23 days) [41]. CRS onset appears to be earlier in lymphoma trials. 
The key cytokine mediator is IL-6. Tocilizumab, the IL-6 receptor antibody, is the first-line of therapy.

Compartmental CRS (C-CRS) has been reported in a patient with advanced ovarian cancer treated with mesothelin-targeted CAR T cells [49]. In this case, elevation of IL- 6 and accumulation of CAR T cells were seen in the pleural fluid. Tocilizumab therapy was effective. C-CRS was also reported in the brain, where IL-6, IFN gamma, and CAR $\mathrm{T}$ cells were significantly higher in the CSF than in the blood [50]. High-dose methylprednisolone successfully alleviated the cerebral CRS.

\section{CRS modeling}

\section{Establishment of CRS mouse models}

CRS remains as a major life-threatening complication with complex pathogenesis. To further study and to better therapy of CRS, two mouse models have been reported [51, 52]. One model used SCID-beige mouse [51]. Raji tumor cells were injected intraperitoneally and allowed to grow 3 weeks. The tumor cells formed vascularized solid masses. Thirty million human $1928 \mathrm{z}$ CAR $\mathrm{T}$ cells were used to target the B leukemia cells and solicit CRS, which occurred 2-3 days after CAR $\mathrm{T}$ infusion. The mouse model recapitulated the constellation of CRS symptoms and signs. Serum cytokines of human origin, IL-2, IL-3, IL-6, IFN gamma, and GMCSF were elevated in CRS.

The other mouse model used humanized NSG mice which produce human cytokines of IL-3, stem cell factor, and GM-CSF to support and enhance hematopoiesis from human stem cells [52]. Patient-derived ALL cell line, ALL-CM, was used as targets for CD19.BBz and CD19.28z CAR T cells. After the CAR T cell challenge, a violent systemic inflammatory syndrome occurred, recapitulating severe human CRS.

\section{Macrophages and monocytes are mediators of CRS}

Using the SCID-beige mouse model, Sadelain's group chased after the source of IL-6 released during CRS. The source was traced to macrophages. It was discovered through RNA-seq analysis that the main source of IL-6 came from the macrophages and monocytes. Production of major inflammatory cytokines was confined to the site of CAR T cell-tumor tissue colocalization in the peritoneum.

In the humanized NSG model, monocytes were found to be the main source of CRS cytokines. Monocyte depletion essentially abolished CRS and protected mice from CRS-induced lethality.

These two separate mouse model systems independently confirmed that macrophages and monocytes are the direct mediators of CRS, not CAR T cells.

\section{IL-1 is the primary cytokine for CRS and CRES}

It is well known that IL- 6 is elevated in patients with CRS, and IL-6 receptor antagonist, tocilizumab, is an effective therapy for CRS. This was reproducible in the mouse models. However, it was demonstrated in both models that IL-1 is the primary cytokine responsible for both CRS and CRES. Blocking IL-1 receptor with anakinra effectively abolished CRS as well as neurotoxicities, whereas blockage of IL-6 with tocilizumab abrogated only CRS, not neurotoxicities. It is known that macrophages/monocytes produce IL-1 upon activation, and IL-1 in turn can elicit production of IL-6 by the macrophages/monocytes. Sadelain's group further demonstrated that by engineering CAR $\mathrm{T}$ cells to constitutively express an IL-1 receptor antagonist, CRS was prevented [51].

\section{Hypotension associated with CRS is induced by nitrogen oxide (NO)}

It was further demonstrated in the SCID-beige mouse model that NO synthetase (NOS) was induced by IL-1 and IL-6 during CRS. As a result, NO production by macrophages was increased, leading to hypotension which is a major life-threatening complication of CAR T-induced severe CRS. Using NOS inhibitors, L-NIL or $1400 \mathrm{~W}$, the investigators were able to alleviate the systemic toxicities and reduce mortality secondary to severe CRS. These findings provided new evidence for CRS pathophysiology and a new means to possibly prevent and effectively treat severe CRS. Inhibition of NOS activity may significantly reduce CRS severity and possibly eliminate or reduce requirements for ICU care of CRS toxicity.

NOS was downregulated by blocking either IL-1 or IL-6, leading to reduced mortality in the mouse model. This confirms that upregulation of NOS is a unifying mechanism for both IL-1- and IL-6-induced severe CRS. However, simultaneous blockade of IL- 1 and IL- 6 does not further reduce the fraction of NOS+ macrophages [51]. This implies that clinically only blocking one of the two cytokines is needed to abrogate CRS.

\section{Blocking CRS does not reduce CAR T functions}

There have been concerns that treatment for CRS could reduce the activity of CAR T cells. Therefore prophylaxis for CRS by steroids and IL- 6 blockage has not been encouraged currently in the clinical practice.

This question was specifically addressed in the mouse models. Using the IL-1R antagonist producing CAR T cells, it was demonstrated that blocking CRS did not reduce the $1928 \mathrm{z}$ CAR T cell antitumor efficacy. Therefore, preventing CRS does not affect CAR $\mathrm{T}$ cell functions. The preservation of antitumor efficacy was also demonstrated where similar leukemia clearance by CAR T cells in the humanized HuSGM3 mice treated with either tocilizumab or anakinra [52] occurred. These observations suggest that clinically it may be preferred to 
apply tocilizumab as early as prophylaxis for CRS so that morbidity and mortality from CART-related toxicities (CARTox) can be significantly reduced.

\section{IL-1 mediates both CRS and CRES}

In the HuSGM3 mouse model, occurrence of lethal neurological syndrome with paralysis and seizures was unexpectedly observed in the mice that received either vehicle or tocilizumab. Meningeal thickening together with human macrophage infiltration in these mice was demonstrated. It was further shown that the meningeal thickening was prevented by administration of anakinra, but not by tocilizumab, even though CRS was effectively abolished by both agents. It was concluded that only anakinra prophylaxis prevented both CRS and neurotoxicity and increased mice survival. This study established that both IL-1 and IL-6 are causal cytokines for CRS, though IL-1 is responsible for severe neurotoxicities (CRES).

\section{New approach for clinical management of CRS and CRES} Currently, for early-onset CRES, such as confusion, hallucination, aphasia, and seizure, steroids are generally used first. For CRS characterized by high fever, hypotension, and hypoxia, tocilizumab is infused over an hour. The dosage is calculated according to patients' weight. For patients' weight less than $30 \mathrm{~kg}$, the dosage is $12 \mathrm{mg} / \mathrm{kg}$, whereas the dosage is $8 \mathrm{mg} / \mathrm{kg}$ when the weight is more than $30 \mathrm{~kg}$ (for official recommendations, please refer to the full prescribing information at https:// www.gene.com/download/pdf/actemra_prescribing.pdf). The treatment can be repeated when clinically necessary, up to three more doses, at least 8 hours apart.

With the new discovery of IL-1 being a major cytokine for both CRS and CRES from the mouse models, it is reasonable to consider anakinra, an IL-1R antagonist, for CAR T-induced toxicities (CARTox), namely, CRS and CRES. Since blocking CARTox has no adverse effect on CAR T antitumor efficacy, it is reasonable to use anakinra or tocilizumab for CRS prophylaxis. Anakinra may be the preferred agent for prophylaxis since it is effective to prevent both CRS and CRES. Tocilizumab may be used to prevent CRS but not effective for prophylaxis of neurotoxicities. In the SCID-beige mouse model, NOS inhibitors were shown to reduce systemic toxicities of CRS. Therefore, these agents may have potential for the management of CARTox and reduce the use of vasopressors. However, these were reports from animal models. Clinical trials are needed to confirm the effect of anakinra for both CRS and CRES as well as NOS inhibitors. Once it is confirmed clinically, a significant reduction in CARTox is expected in the near future. Clinical confirmation of these significant findings from mouse models is urgently needed.

Currently, tocilizumab is being studied in a clinical trial for prophylaxis of CRS (Table 2). Since it has been observed that CRS severity is directly related to leukemia burden in ALL and severe CRS occurs earlier, timing of tocilizumab therapy is being studied in a two-cohort open-label pilot study (Table 2). Tocilizumab is scheduled to start earlier in high-leukemia-burden patients.

\section{Conclusions}

Currently, there are several CRS scoring models (Table 1). These were used for different clinical trials. It is ideal to have a consensus and to unify the scoring systems. There is no CRES-specific scoring system available yet. In addition to prophylaxis, new CAR design is needed to better control and adjust the CAR T cell engagement of target cancer cells. SUPRA CAR design offers a flexible, switchable, and more adjustable construct as demonstrated in the mouse model [53]. This SUPRA CAR design may bring more control in CRS. Clinical trial of the SUPRA CAR T cells is clearly needed.

Blinatumomab is a bispecific $\mathrm{T}$ cell engager (BiTE) approved for therapy of acute lymphoblastic leukemia [54-56]. Bispecific antibodies are associated with the similar profile of CRES and CRS seen in CAR T therapy, albeit at a lower incidence and with less severity [57-59]. Since the pathophysiology of the CRS and CRES incited by blinatumomab is similar to CARTox,

Table 2 Clinical trials of tocilizumab for cytokine release syndrome

\begin{tabular}{|c|c|c|c|c|}
\hline NCT no. & Trials & Conditions & Interventions & Locations \\
\hline 03533101 & $\begin{array}{l}\text { Tocilizumab for Cytokine Release Syndrome } \\
\text { Prophylaxis in Haploidentical Transplantation }\end{array}$ & $\begin{array}{l}\text {-Cytokine release syndrome } \\
\text {-Stem cell } \\
\text { transplant complications }\end{array}$ & -Drug: tocilizumab & $\begin{array}{l}\text {-Hospital Universitario Dr. Jose } \\
\text { E Gonzalez UANL, Monterrey, } \\
\text { Nuevo Leon, Mexico }\end{array}$ \\
\hline 03275493 & $\begin{array}{l}\text { Humanized CD19 CAR-T Cells With CRS } \\
\text { Suppression Technology for } r / r \text { CD19+ } \\
\text { Acute Lymphoblastic Leukemia }\end{array}$ & $\begin{array}{l}\text {-Acute lymphoblastic } \\
\text { leukemia } \\
\text {-CD19 positive } \\
\text { - Relapse } \\
\text { - Refractory }\end{array}$ & $\begin{array}{l}\text { •Biological: humanized } \\
\text { CD19 CAR-T cells } \\
\text {-Biological: humanized } \\
\text { CD19 CAR-T cells with } \\
\text { CRS suppression technology }\end{array}$ & $\begin{array}{l}\text {-The First Affiliated Hospital of } \\
\text { Soochow University, Suzhou, } \\
\text { Jiangsu, China }\end{array}$ \\
\hline 02906371 & $\begin{array}{l}\text { Study of the Tocilizumab Optimization Timing } \\
\text { for CART19 Associated Cytokine Release } \\
\text { Syndrome }\end{array}$ & $\begin{array}{l}\text {-Lymphoblastic leukemia, } \\
\text { acute, childhood }\end{array}$ & $\begin{array}{l}\text {-Drug: tocilizumab } \\
\text {-Biological: CART } 19\end{array}$ & $\begin{array}{l}\text {-Children's Hospital of } \\
\text { Philadelphia, Philadelphia, } \\
\text { PA, USA }\end{array}$ \\
\hline
\end{tabular}


and IL-6 blockade is equally effective for CRS, it is possible that macrophage-produced IL-1 plays a major role in the toxicities [42]. Therefore, anakinra may be a therapeutic and prophylactic option for the CRS and CRES associated with blinatumomab. Clinical trial of anakinra is indicated.

A variety of systemic inflammatory syndromes, such as acute respiratory distress syndrome (ARDS) and macrophage activation syndrome/hemophagocytic lymphohistiocytosis (HLH), have similar clinical manifestations with high fever, hypoxia, and hypotension. The findings from the CRS models appear to be provocative for implications of management for ARDS and HLH. Etanercept, a soluble TNFa receptor, has been used successfully for CRS therapy [42]. It is possible that IL-1 and/or IL-6 is also a major cytokine for the syndromes [60-62]. Further studies on use of anakinra and/or tocilizumab in these syndromes would be indicated. A clinical trial of tocilizumab for HLH is underway (NCT02007239).

\section{Abbreviations}

CAR: Chimeric antigen receptor; CRES: CAR-related encephalopathy syndrome; CRS: Cytokine release syndrome

\section{Funding}

The study is partly supported by the First Affiliated Hospital of Zhengzhou University, Zhengzhou, China.

\section{Availability of data and materials}

The material supporting the conclusion of this review has been included within the article.

\section{Authors' contributions}

$\mathrm{DL}$ designed the study and drafted the manuscript. JZ prepared the table. Both authors read and approved the final manuscript.

\section{Ethics approval and consent to participate}

This is not applicable for this review.

\section{Consent for publication}

This is not applicable for this review.

\section{Competing interests}

The authors declare that they have no competing interests.

\section{Publisher's Note}

Springer Nature remains neutral with regard to jurisdictional claims in published maps and institutional affiliations.

\section{Author details}

'Department of Oncology, The First Affiliated Hospital of Zhengzhou University, Zhengzhou 450052, China. ${ }^{2}$ The Affiliated Cancer Hospital of Zhengzhou University and Henan Cancer Hospital, 127 Dongming Road, Zhengzhou 450008, China.

Received: 18 July 2018 Accepted: 15 August 2018 Published online: 24 September 2018

\section{References}

1. June $\mathrm{CH}$, O'Connor RS, Kawalekar OU, Ghassemi S, Milone MC. CAR T cell immunotherapy for human cancer. Science. 2018;359(6382):1361-5.

2. June $\mathrm{CH}$, Sadelain M. Chimeric antigen receptor therapy. N Engl J Med. 2018:379(1):64-73.

3. Sadelain M, Brentjens R, Riviere I. The basic principles of chimeric antigen receptor design. Cancer Discov. 2013;3(4):388-98.
4. Sadelain M, Brentjens R, Riviere I, Park J. CD19 CAR therapy for acute lymphoblastic leukemia. Am Soc Clin Oncol Educ Book. 2015:e360-3.

5. Sadelain $\mathrm{M}$, Rivière I, Riddell $\mathrm{S}$. Therapeutic $\mathrm{T}$ cell engineering. Nature. 2017;545:423.

6. Lim WA, June $\mathrm{CH}$. The principles of engineering immune cells to treat cancer. Cell. 2017;168(4):724-40.

7. Fraietta JA, Beckwith KA, Patel PR, Ruella M, Zheng Z, Barrett DM, Lacey SF, Melenhorst JJ, McGettigan SE, Cook DR, Zhang C, Xu J, Do P, Hulitt J, Kudchodkar SB, Cogdill AP, Gill S, Porter DL, Woyach JA, Long M, Johnson AJ, Maddocks K, Muthusamy N, Levine BL, June CH, Byrd JC, Maus MV. Ibrutinib enhances chimeric antigen receptor T-cell engraftment and efficacy in leukemia. Blood. 2016;127(9):1117-27.

8. Fraietta JA, Lacey SF, Orlando EJ, Pruteanu-Malinici I, Gohil M, Lundh S, Boesteanu AC, Wang Y, O'Connor RS, Hwang WT, Pequignot E, Ambrose DE, Zhang C, Wilcox N, Bedoya F, Dorfmeier C, Chen F, Tian L, Parakandi H, Gupta M, Young RM, Johnson FB, Kulikovskaya I, Liu L, Xu J, Kassim SH, Davis MM, Levine BL, Frey NV, Siegel DL, et al. Determinants of response and resistance to CD19 chimeric antigen receptor (CAR) T cell therapy of chronic lymphocytic leukemia. Nat Med. 2018;24(5):563-71.

9. Liu B, Song Y, Liu D. Clinical trials of CAR-T cells in China. J Hematol Oncol. 2017:10(1):166.

10. Maude SL, Frey N, Shaw PA, Aplenc R, Barrett DM, Bunin NJ, Chew A, Gonzalez VE, Zheng Z, Lacey SF, Mahnke YD, Melenhorst JJ, Rheingold SR, Shen A, Teachey DT, Levine BL, June CH, Porter DL, Grupp SA. Chimeric antigen receptor T cells for sustained remissions in leukemia. N Engl J Med. 2014;371(16):1507-17.

11. Neelapu SS, Locke FL, Bartlett NL, Lekakis L, Miklos D, Jacobson CA, Braunschweig I, Oluwole O, Siddiqi T, Lin Y, Timmerman J, Stiff PJ, Friedberg J, Flinn I, Goy A, Smith M, Deol A, Farooq U, McSweeney P, Munoz J, Avivi I, Castro JE, Westin JR, Chavez JC, Ghobadi A, Komanduri KV, Levy R, Jacobsen ED, Reagan P, Bot A, et al. Kte-C19 (anti-CD19 CAR T cells) induces complete remissions in patients with refractory diffuse large B-cell lymphoma (DLBCL): results from the pivotal phase 2 Zuma-1. Blood. 2016;128(22):LBA-6-LBA-6.

12. Porter $\mathrm{DL}$, Levine $\mathrm{BL}$, Kalos $\mathrm{M}$, Bagg $\mathrm{A}$, June $\mathrm{CH}$. Chimeric antigen receptormodified T cells in chronic lymphoid leukemia. N Engl J Med. 2011;365(8): $725-33$.

13. Qin L, Lai $Y$, Zhao R, Wei X, Weng J, Lai P, Li B, Lin S, Wang S, Wu Q, Liang Q, Li Y, Zhang X, Wu Y, Liu P, Yao Y, Pei D, Du X, Li P. Incorporation of a hinge domain improves the expansion of chimeric antigen receptor $\mathrm{T}$ cells. J Hematol Oncol. 2017;10(1):68.

14. Qin L, Zhao R, Li P. Incorporation of functional elements enhances the antitumor capacity of CAR T cells. Experimental Hematology \& Oncology. 2017:6(1):28

15. Ribas A. Releasing the brakes on cancer immunotherapy. N Engl J Med. 2015:373(16):1490-2.

16. Song D-G, Ye Q, Poussin M, Chacon JA, Figini M, Powell DJ. Effective adoptive immunotherapy of triple-negative breast cancer by folate receptor-alpha redirected CAR T cells is influenced by surface antigen expression level. J Hematol Oncol. 2016;9(1):56.

17. Wang Z, Wu Z, Liu Y, Han W. New development in CAR-T cell therapy. J Hematol Oncol. 2017:10(1):53.

18. Wei G, Ding L, Wang J, Hu Y, Huang H. Advances of CD19-directed chimeric antigen receptor-modified $\mathrm{T}$ cells in refractory/relapsed acute lymphoblastic leukemia. Experimental Hematology \& Oncology. 2017;6(1):10.

19. Yu S, Li A, Liu Q, Li T, Yuan X, Han X, Wu K. Chimeric antigen receptor T cells: a novel therapy for solid tumors. J Hematol Oncol. 2017;10(1):78.

20. Brown CE, Alizadeh D, Starr R, Weng L, Wagner JR, Naranjo A, Ostberg JR, Blanchard MS, Kilpatrick J, Simpson J, Kurien A, Priceman SJ, Wang X, Harshbarger TL, D'Apuzzo M, Ressler JA, Jensen MC, Barish ME, Chen M, Portnow J, Forman SJ, Badie B. Regression of glioblastoma after chimeric antigen receptor T-cell therapy. N Engl J Med. 2016;375(26):2561-9.

21. Locke FL, Neelapu SS, Bartlett NL, Siddiqi T, Chavez JC, Hosing CM, Ghobadi A, Budde LE, Bot A, Rossi JM, Jiang Y, Xue AX, Elias M, Aycock J, Wiezorek J, Go WY. Phase 1 results of ZUMA-1: a multicenter study of KTE-C19 anti-CD19 CAR T cell therapy in refractory aggressive lymphoma. Mol Ther. 2017;25(1):285-95.

22. Maude SL, Laetsch TW, Buechner J, Rives S, Boyer M, Bittencourt H, Bader P, Verneris MR, Stefanski HE, Myers GD, Qayed M, De Moerloose B, Hiramatsu H, Schlis K, Davis KL, Martin PL, Nemecek ER, Yanik GA, Peters C, Baruchel A, Boissel N, Mechinaud F, Balduzzi A, Krueger J, June CH, Levine BL, Wood P, Taran T, Leung M, Mueller KT, et al. Tisagenlecleucel in children and young adults with B-cell lymphoblastic leukemia. N Engl J Med. 2018;378(5):439-48. 
23. Rosenbaum L. Tragedy, perseverance, and chance — the story of CAR-T therapy. N Engl J Med. 2017;377(0) https://doi.org/10.1056/NEJMp1711886.

24. Zhang C, Liu J, Zhong JF, Zhang X. Engineering CAR-T cells. Biomarker Research. 2017;5(1):22

25. Zhang $\mathrm{E}, \mathrm{Xu} \mathrm{H}$. A new insight in chimeric antigen receptor-engineered $\mathrm{T}$ cells for cancer immunotherapy. J Hematol Oncol. 2017;10(1):1.

26. Zhang L, Tai Y-T, Ho MZG, Qiu L, Anderson KC. Interferon-alpha-based immunotherapies in the treatment of B cell-derived hematologic neoplasms in today's treat-to-target era. Experimental Hematology \& Oncology. 2017;6(1):20.

27. Casucci M, Falcone L, Camisa B, Norelli M, Porcellini S, Stornaiuolo A, Ciceri F, Traversari C, Bordignon C, Bonini C, Bondanza A. Extracellular NGFR spacers allow efficient tracking and enrichment of fully functional CAR-T cells co-expressing a suicide gene. Front Immunol. 2018;9:507.

28. Fan M, Li M, Gao L, Geng S, Wang J, Wang Y, Yan Z, Yu L. Chimeric antigen receptors for adoptive $T$ cell therapy in acute myeloid leukemia. J Hematol Oncol. 2017;10(1):151.

29. Cho JH, Collins JJ, Wong WW. Universal chimeric antigen receptors for multiplexed and logical control of T cell responses. Cell. 2018;173(6):1426-38.

30. O'Rourke DM, Nasrallah M, Morrissette JJ, Melenhorst JJ, Lacey SF, Mansfield K, Martinez-Lage M, Desai AS, Brem S, Maloney E, Mohan S, Wang S, Verma G, Navenot J-M, Shen A, Zheng Z, Levine B, Okada H, June CH, Maus MV. Pilot study of T cells redirected to EGFRvIll with a chimeric antigen receptor in patients with EGFRvIll+ glioblastoma. J Clin Oncol. 2016;34(15_suppl):2067.

31. Shibahara I, Saito R, Zhang R, Chonan M, Shoji T, Kanamori M, Sonoda Y, Kumabe T, Kanehira M, Kikuchi T, So T, Watanabe T, Takahashi H, Iwabuchi E, Tanaka Y, Shibahara Y, Sasano H, Ishii N, Tominaga T. OX40 ligand expressed in glioblastoma modulates adaptive immunity depending on the microenvironment: a clue for successful immunotherapy. Mol Cancer. 2015;14:41.

32. Turtle CJ, Hanafi LA, Berger C, Hudecek M, Pender B, Robinson E, Hawkins R, Chaney C, Cherian S, Chen X, Soma L, Wood B, Li D, Heimfeld S, Riddell SR, Maloney DG. Immunotherapy of non-Hodgkin's lymphoma with a defined ratio of CD8+ and CD4+ CD19-specific chimeric antigen receptor-modified T cells. Sci Transl Med. 2016;8(355):355ra116.

33. Ueno H, Blanco P. OX40/OX40L axis: not a friend in autoimmunity. Oncotarget. 2015;6(26):21779-80.

34. Wang $C M$, Wu ZQ, Wang $Y$, Guo $Y L$, Dai HR, Wang $X H$, Li $X$, Zhang $Y$ J, Zhang WY, Chen MX, Zhang Y, Feng KC, Liu Y, Li SX, Yang QM, Han WD. Autologous T cells expressing CD30 chimeric antigen receptors for relapsed or refractory Hodgkin lymphoma: an open-label phase I trial. Clin Cancer Res. 2017;23(5):1156-66.

35. Wang QS, Wang Y, Lv HY, Han QW, Fan H, Guo B, Wang LL, Han WD. Treatment of CD33-directed chimeric antigen receptor-modified T cells in one patient with relapsed and refractory acute myeloid leukemia. Mol Ther. 2015;23(1):184-91.

36. Wang Y, Chen M, Wu Z, Tong C, Huang J, Lv H, Dai H, Feng K, Guo Y, Liu Y, Yang Q, Han W. CD133-redirected chimeric antigen receptor engineered autologous T-cell treatment in patients with advanced and metastatic malignancies. J Clin Oncol. 2017;35(15_suppl):3042.

37. Zhai B, Shi D, Gao H, Qi X, Jiang H, Zhang Y, Chi J, Ruan H, Wang H, Ru QC, Li Z. A phase I study of anti-GPC3 chimeric antigen receptor modified T cells (GPC3 CAR-T) in Chinese patients with refractory or relapsed GPC3+ hepatocellular carcinoma ( $r / r$ GPC3+ HCC). Journal of Clinical Oncology. 2017;35(15_suppl):3049.

38. Hegde M, Wakefield A, Brawley VS, Grada Z, Byrd TT, Chow KK, Krebs SS, Heslop HE, Gottschalk SM, Yvon E, Ahmed N. Genetic modification of T cells with a novel bispecific chimeric antigen receptor to enhance the control of high-grade glioma (HGG). J Clin Oncol. 2014;32(15_suppl):10027.

39. Hege KM, Bergsland EK, Fisher GA, Nemunaitis JJ, Warren RS, McArthur JG, Lin AA, Schlom J, June $\mathrm{CH}$, Sherwin SA. Safety, tumor trafficking and immunogenicity of chimeric antigen receptor (CAR)-T cells specific for TAG72 in colorectal cancer. J Immunother Cancer. 2017;5:22.

40. Wang Z, Han W. Biomarkers of cytokine release syndrome and neurotoxicity related to CAR-T cell therapy. Biomarker Research. 2018;6(1):4.

41. Porter D, Frey N, Wood PA, Weng Y, Grupp SA. Grading of cytokine release syndrome associated with the CAR T cell therapy tisagenlecleucel. J Hematol Oncol. 2018;11(1):35.

42. Lee DW, Gardner R, Porter DL, Louis CU, Ahmed N, Jensen M, Grupp SA, Mackall CL. Current concepts in the diagnosis and management of cytokine release syndrome. Blood. 2014;124(2):188-95.
43. Neelapu SS, Tummala S, Kebriaei P, Wierda W, Gutierrez C, Locke FL, Komanduri KV, Lin Y, Jain N, Daver N, Westin J, Gulbis AM, Loghin ME, de Groot JF, Adkins S, Davis SE, Rezvani K, Hwu P, Shpall EJ. Chimeric antigen receptor T-cell therapy - assessment and management of toxicities. Nat Rev Clin Oncol. 2018;15(1):47-62.

44. Neelapu SS, Tummala S, Kebriaei P, Wierda W, Locke FL, Lin Y, Jain N, Daver N, Gulbis AM, Adkins S, Rezvani K, Hwu P, Shpall EJ. Toxicity management after chimeric antigen receptor T cell therapy: one size does not fit 'ALL'. Nat Rev Clin Oncol. 2018;15(4):218.

45. Park JH, Rivière I, Gonen M, Wang X, Sénéchal B, Curran KJ, Sauter C, Wang Y, Santomasso B, Mead E, Roshal M, Maslak P, Davila M, Brentjens RJ, Sadelain M. Long-term follow-up of CD19 CAR therapy in acute lymphoblastic leukemia. N Engl J Med. 2018;378:449-59.

46. Santomasso BD, Park JH, Salloum D, Riviere I, Flynn J, Mead E, Halton E, Wang X, Senechal B, Purdon T, Cross JR, Liu H, Vachha B, Chen X, DeAngelis LM, Li D, Bernal Y, Gonen M, Wendel HG, Sadelain M, Brentjens RJ. Clinical and biologic correlates of neurotoxicity associated with CAR T cell therapy in patients with B-cell acute lymphoblastic leukemia (B-ALL). Cancer Discov. 2018;8(8):958-971.

47. Zhang L-N, Song Y, Liu D. CD19 CAR-T cell therapy for relapsed/refractory acute lymphoblastic leukemia: factors affecting toxicities and long-term efficacies. Journal of Hematology \& Oncology. 2018;11(1):41.

48. Fraietta JA, Nobles CL, Sammons MA, Lundh S, Carty SA, Reich TJ, Cogdill AP, Morrissette JJD, DeNizio JE, Reddy S, Hwang Y, Gohil M, Kulikovskaya I, Nazimuddin F, Gupta M, Chen F, Everett JK, Alexander KA, Lin-Shiao E, Gee MH, Liu X, Young RM, Ambrose D, Wang Y, Xu J, Jordan MS, Marcucci KT, Levine BL, Garcia KC, Zhao Y, et al. Disruption of TET2 promotes the therapeutic efficacy of CD19-targeted T cells. Nature. 2018;558(7709):307-12.

49. Tanyi JL, Stashwick C, Plesa G, Morgan MA, Porter D, Maus MV, June CH. Possible compartmental cytokine release syndrome in a patient with recurrent ovarian cancer after treatment with mesothelin-targeted CAR-T cells. J Immunother. 2017;40(3):104-7.

50. Hu Y, Sun J, Wu Z, Yu J, Cui Q, Pu C, Liang B, Luo Y, Shi J, Jin A, Xiao L, Huang $\mathrm{H}$. Predominant cerebral cytokine release syndrome in CD19directed chimeric antigen receptor-modified T cell therapy. J Hematol Oncol. 2016;9(1):70.

51. Giavridis T, van der Stegen SJC, Eyquem J, Hamieh M, Piersigilli A, Sadelain M. CAR T cell-induced cytokine release syndrome is mediated by macrophages and abated by IL-1 blockade. Nat Med. 2018;24(6):731-8.

52. Norelli M, Camisa B, Barbiera G, Falcone L, Purevdorj A, Genua M, Sanvito F, Ponzoni M, Doglioni C, Cristofori P, Traversari C, Bordignon C, Ciceri F, Ostuni R, Bonini C, Casucci M, Bondanza A. Monocyte-derived IL-1 and IL-6 are differentially required for cytokine-release syndrome and neurotoxicity due to CAR T cells. Nat Med. 2018;24(6):739-48.

53. Chen YY. Increasing T Cell Versatility with SUPRA CARs. Cell. 2018;173(6):1316-7.

54. Topp MS, Gokbuget N, Stein AS, Zugmaier G, O'Brien S, Bargou RC, Dombret H, Fielding AK, Heffner L, Larson RA, Neumann S, Foa R, Litzow M, Ribera JM, Rambaldi A, Schiller G, Bruggemann M, Horst HA, Holland C, Jia C, Maniar T, Huber B, Nagorsen D, Forman SJ, Kantarjian HM. Safety and activity of blinatumomab for adult patients with relapsed or refractory Bprecursor acute lymphoblastic leukaemia: a multicentre, single-arm, phase 2 study. Lancet Oncol. 2014;16(1):57-66.

55. Zugmaier G, Goekbuget N, Viardot A, Stelljes M, Neumann S, Horst HA, Reichle A, Marks R, Faul C, Brueggemann M, Holland C, Schmidt M, Mergen N, Goebeler M-E, Einsele H, Bargou RC, Topp MS. Long-term survival in adult patients with relapsed/refractory B-precursor acute lymphoblastic leukemia (ALL) who achieved minimal residual disease (MRD) response following anti-CD19 BiTE ${ }^{\oplus}$ blinatumomab. Blood. 2014;124(21):2287.

56. Zugmaier G, Topp MS, Alekar S, Viardot A, Horst HA, Neumann S, Stelljes M, Bargou RC, Goebeler M, Wessiepe D, Degenhard E, Gokbuget N, Klinger M. Long-term follow-up of serum immunoglobulin levels in blinatumomabtreated patients with minimal residual disease-positive B-precursor acute lymphoblastic leukemia. Blood Cancer J. 2014;4:244.

57. Yu S, Li A, Liu Q, Yuan X, Xu H, Jiao D, Pestell RG, Han X, Wu K. Recent advances of bispecific antibodies in solid tumors. J Hematol Oncol. 2017;10(1):155.

58. Yu S, Liu Q, Han X, Qin S, Zhao W, Li A, Wu K. Development and clinical application of anti-HER2 monoclonal and bispecific antibodies for cancer treatment. Experimental Hematology \& Oncology. 2017;6(1):31. 
59. Zhang $X$, Yang $Y$, Fan D, Xiong D. The development of bispecific antibodies and their applications in tumor immune escape. Experimental Hematology \& Oncology. 2017:6(1):12.

60. Flammiger A, Fiedler W, Bacher U, Bokemeyer C, Schneider M, Binder M.

Critical imbalance of TNF-alpha and soluble TNF receptor 1 in a patient with macrophage activation syndrome: potential implications for diagnostics and treatment. Acta Haematol. 2012;128(2):69-72.

61. Prahalad S, Bove KE, Dickens D, Lovell DJ, Grom AA. Etanercept in the treatment of macrophage activation syndrome. J Rheumatol. 2001;28(9):2120-4.

62. Gabay C, Lamacchia C, Palmer G. IL-1 pathways in inflammation and human diseases. Nat Rev Rheumatol. 2010;6(4):232-41.

Ready to submit your research? Choose BMC and benefit from:

- fast, convenient online submission

- thorough peer review by experienced researchers in your field

- rapid publication on acceptance

- support for research data, including large and complex data types

- gold Open Access which fosters wider collaboration and increased citations

- maximum visibility for your research: over $100 \mathrm{M}$ website views per year

At BMC, research is always in progress.

Learn more biomedcentral.com/submissions 